\title{
PLANT SCIENCE
}

\section{Agronomic performance of mash bean as an intercrop in sesame under different planting patterns}

\author{
Iftikhar H. Bhatti ${ }^{12^{*}}$, Riaz Ahmad ${ }^{1}$, Abdul Jabbar ${ }^{1}$, Muhammad Nadeem ${ }^{3}$, Muhammad M. Khan ${ }^{4}$, Wasi- \\ ud-Din $^{1}$ and Shah N. Vains ${ }^{1,5}$ \\ ${ }^{1}$ Department of Agronomy, University of Agriculture, Faisalabad, Pakistan \\ ${ }^{2}$ Directorate of Extention and Adaptive Research, Lahore, Pakistan \\ ${ }^{3}$ Department of Farm Machinery, University of Agriculture, Faisalabad, Pakistan \\ ${ }^{4}$ Engro Fertilizers (Pvt) Gujranwala, Pakistan \\ ${ }^{5}$ Sugar Research Institute, Shakar Ganj Mills, Jhang, Pakistan
}

\begin{abstract}
In a field study, the performance of mashbean in a sesame-mash intercropping system under different geometric arrangements was evaluated on a sandy-clay loam soil at the University of Agriculture, Faisalabad for two consecutive years. The planting pattern comprised $40 \mathrm{~cm}$ spaced single rows, $60 \mathrm{~cm}$ spaced 2-row strips and $100 \mathrm{~cm}$ spaced 4-row strips while mashbean was intercropped in all the three planting patterns and also grown as sole crop. The results revealed that planting sesame in the pattern of $100 \mathrm{~cm}$ spaced 4-row strips explored the possibility of intercropping mashbean in sesame by producing significantly maximum seed yield of mashbean $\left(703.10 \mathrm{~kg} \mathrm{ha}^{-1}\right)$ and base crop i.e. sesame $\left(687.40 \mathrm{~kg} \mathrm{ha}^{-1}\right)$ as compared to $40 \mathrm{~cm}$ spaced single rows and $60 \mathrm{~cm}$ spaced 2-row strips planting patterns. Besides, the intercropping sesame with mashbean in pattern of $100 \mathrm{~cm}$ spaced 4-row strips appeared to be feasible, convenient and gave maximum net profit (Rs.21242 ha ${ }^{-1}$ ) as compared to other two planting patterns and monocropped sesame.
\end{abstract}

Key words: Agronomic performance, Planting patterns, Intercropping, Sesame

\section{Introduction}

The role of legumes as a source of vegetable protein and their beneficial effects on residual soil fertility is well known. Unfortunately, these crops being grown on poor soils of rain fed areas could not benefit from the impact of green revolution, which resulted in chronic low yield and shortage of pulses in country for the last many years. At present the gross domestic production of pulses in Pakistan is 937.30 thousand tones with net availability of $680.68 \mathrm{~kg} \mathrm{ha}^{-1}$ annum $^{-1}$. Pakistan spent 92.2 million dollars on import of pulses to meet the growing need of her population (Anonymous, 2012) by spending huge amount of foreign exchange.

In view of shrinkage resources particularly arable land, area, irrigation water and energy, the only option left is to increase the production per unit area/time. Of the possible agronomic

Received 09 February 2011; Revised 14 July 2011; Accepted 26 August 2011; Published Online 24 November 2012

*Corresponding Author

Iftikhar H. Bhatti

Department of Agronomy, University of Agriculture,

Faisalabad, Pakistan

Email: jabbaruafap@yahoo.com approaches to meet this challenge, an intercropping technology is an immediate option since it as been a proven technology for the last many years in IndoPak subcontinent and is now showing commercial prospects (Jabbar et al., 2005; Ahmad et al., 2007; Jabbar et al., 2011). In the past, monocropping of grain legumes (pulses) was a usual practice among the growers but now-a-days the interest in growing food legumes as intercrops is increasing. Recent evidence suggests that there are remarkable benefits of legumes intercropping which are achieved not only by means of costly inputs but by the simple expedient of growing crops together in an appropriate geometry (Bhatti at el., 2008). When legumes are grown in association with nonlegumes, there is often advantage to the nonlegumes from nitrogen fixed by the legumes (Wahla et al., 2009). Besides, two crops differing in height, canopy, adaptation and growth habits grow simultaneously with least competition (Jabbar et al., 2009). Other suggested forms of advantages are the greater stability of yield over different seasons, better use of land resources, possibility of better control of weeds, pests and diseases (Jabbar et al., 2010a,b). 
Pakistan is a subtropical country having adequate irrigation and land resources with high intensity of sunlight for plant growth. Therefore, possibility of raising two or more crops on the same piece of land in a year needs to be explored for effective and efficient utilization of these natural resources. Intercropping is an efficient and most economical production system as it not only increases the production per unit area and time but also improves the resource-use efficiency and economic standard of the growers. Presently, interest in intercropping is emerging among the small growers because of their diversified needs and low farm income from the monocropping system.

So in the present scenario of preponderance of small holding, surplus farm family labour, overlapping of growing season of crops, low productivity of most of the crops and practice of subsistence farming intercropping seems to be a promising strategy for increasing crop productivity particularly at small farm level in Pakistan.

The conventional method of planting sesame in 40-cm spaced single rows, however, does not permit intercropping because of narrow inter-row spacing. Recently a new method of planting sesame in well-spaced multi-row strips has been developed which not only gives relatively higher seed yield than the conventional single row planting (Nazir et al. (2001) and Jabbar et al. (2011) but also facilitates intercropping, harvesting and handling of the intercrops without doing damage to the base crop.

In Pakistan, no systematic research seems to have been done so far to explore the possibility of intercropping of various legume crops in sesame. Thus, there is a need to develop an appropriate sesame-legume intercropping system. The present study was, therefore, planned to explore the feasibility and production potential of mashbean (Vigna mungo L.) as intercrop in sesame under different planting patterns in irrigated environment at Faisalabad.

\section{Materials and Methods}

The study was conducted at the agronomic research area, University of Agriculture, Faisalabad on a sandy clay loam soil. The planting patterns comprised $40 \mathrm{~cm}$ spaced single rows, $60 \mathrm{~cm}$ spaced 2-row strips and $100 \mathrm{~cm}$ spaced 4-row strips of sesame while mashbean was intercropped in all the three planting patterns and also grown as a sole crop. Mashbean was intercropped in sesame on the same day on the vacant space between the sesame strips. The plant population was kept constant and optimum in all the three geometric arrangements. The experiment was laid out in a randomized complete block design with four replications. The net plot size was $3.2 \mathrm{~m}$ x $7.0 \mathrm{~m}$. A basal dose of 50100-50 kg NPK ha ${ }^{-1}$ was applied at the time of sowing while additional $50 \mathrm{~kg} \mathrm{~N}^{-1}$ was applied with first irrigation only to the sesame crop to meet its full nitrogen requirement. In all three irrigations each of $7.5 \mathrm{~cm}$ were given to mature the component crops. The first irrigation was given 20 days after germination and the second 35 days after germination while the third one at flowering. Both the sesame and mashbean were harvested at their physiological maturity. The crops were harvested manually at the ground level with the help of a sickle, dried in the sun light and then tied into separate bundles. Both the crops were threshed manually. The observations were recorded on the desired parameters as per treatment by using standard procedures. The data collected were statistically analyzed by using the computer statistical programme "MSTAT-C (Freed and Eisensmith, 1986) and Fisher's analysis of variance technique (Steel et al., 1997) and the Least Significant Differences (LSD) test at $\mathrm{P}=0.05$ was used to compare the differences among treatment means.

\section{Results and discussion Seed yield $\left(\mathrm{kg} \mathrm{ha}^{-1}\right)$}

The 2-year average data revealed that mash bean grown as sole crop produced significantly higher seed yield $\left(808.40 \mathrm{~kg} \mathrm{ha}^{-1}\right)$ than that obtained as intercrop in all the three planting patterns (Table 1).

Within the planting patterns, mashbean intercropped in sesame planted in the pattern of 100 $\mathrm{cm}$ spaced 4-row strips produced significantly higher seed yield (703.1. $\mathrm{kg} \mathrm{ha}^{-1}$ ) than that intercropped in $60 \mathrm{~cm}$ spaced paired rows $(621.1 \mathrm{~kg}$ $\mathrm{ha}^{-1}$ ) compared to the minimum (503.70 $\mathrm{kg} \mathrm{ha}^{-1}$ ) when intercropped in sesame planted in $40 \mathrm{~cm}$ spaced ingle rows. Yield reduction in the intercropped mashbean was attributed to less number of branches and pods plant ${ }^{-1}$, less seeds plant $^{-1}$ and lower 1000-seed weight compared to the sole crop of mashbean (Table 1). Suppressive effect of intercropping on different yield components of mashbean grown in association with sesame might be due to variable inter-specific competition for different growth factors. This competition was not severe in case of mashbean intercropped in sesame planted in $100 \mathrm{~cm}$ spaced 4-row strips as compared to its intercropping in $60 \mathrm{~cm}$ spaced single rows. The former planting pattern promoted more light 
and air penetration. Khan and Khaliq (2004) also reported a significant reduction in seed yield of soybeean intercropped in cotton. Similarly Bhatti et al. (2008) also observed significant reduction in seed yield of mungbean due to associated culture in sesame.

\section{Stalk yield (kg ha-1)}

Mashbean grown as a sole crop produced significantly higher stalk yield $\left(2538.00 \mathrm{~kg} \mathrm{ha}^{-1}\right)$ than that realized from mashbean as intercrop in all the three planting patterns (Table 1). However, stalk yield of mashbean intercropped in $100 \mathrm{~cm}$ spaced 4-row strips of sesame was significantly higher $\left(2332.00 \mathrm{~kg} \mathrm{ha}^{-1}\right)$ than that intercropped in $60 \mathrm{~cm}$ spaced paired rows $\left(2133.00 \mathrm{~kg} \mathrm{ha}^{-1}\right)$. By contrast, the minimum stalk yield of mashbean was recorded when intercropped in sesame planted in 40 $\mathrm{cm}$ spaced single rows $\left(1834.00 \mathrm{~kg} \mathrm{ha}^{-1}\right)$.

\section{Biological yield ( $\left.\mathrm{kg} \mathrm{ha}^{-1}\right)$}

Intercropping had a significant effect on the biological yield of mashbean intercrops. However, mashbean grown alone in 40 spaced rows produced significantly higher biological yield $(3335.00 \mathrm{~kg}$ $\mathrm{ha}^{-1}$ ) than that grown as intercrop under different planting patterns (Table 1).

Among the planting patterns, mashbean intercropped in sesame planted in the pattern of 100 $\mathrm{cm}$ spaced 4-row strips gave significantly higher biological yield $(3036.00 \mathrm{~kg} \mathrm{ha}$ ) than that intercropped in the pattern of $60 \mathrm{~cm}$ spaced paired rows $\left(2755 \mathrm{~kg} \mathrm{ha}^{-1}\right)$ against the minimum $(2337 \mathrm{~kg}$ $\mathrm{ha}^{-1}$ ) when mashbean was intercropped in sesame planted in $40 \mathrm{~cm}$ spaced single rows. The variation in biological yield of mashbean intercropped in different planting patterns was attributed to dominant effect of the sesame which suppressed the vegetative growth of mashbean. Similar reduction in biological yield of soybean was reported by Khan and Khaliq (2004) when intercropped in cotton. Similarly Bhatti et al. (2008) also observed significant reduction in biological yield of mungbean when intercropped with sesame.

\section{Number of branches plant ${ }^{-1}$}

Effect of intercropping on branches plant ${ }^{-1}$ of mashbean was significant. Mashbean grown alone in $40 \mathrm{~cm}$ spaced rows produced significantly greater number of branches plant ${ }^{-1}(6.28)$ that that grown as intercrop in different planting patterns (Table 1).

Among the planting patterns, mashbean intercropped in sesame grown as intercrop in the pattern of $100 \mathrm{~cm}$ spaced 4-row strips produced significantly more branches plant ${ }^{-1}(5.07)$ than that intercropped in $60 \mathrm{~cm}$ spaced paired rows (4.64) compared to the minimum (4.15) when mashbean was intercropped in sesame planted in $40 \mathrm{~cm}$ spaced single rows. Significantly less number of branches in intercropped mashbean was attributed to competition between the component crops for growth factors and dominant behaviour of sesame. Similar results were reported by Bhatti et al. (2008) when mungbean was intercropped with sesame. Khan and Khaliq (2004) also reported significant effect on branches plant ${ }^{-1}$ of soybean when intercropped in cotton.

\section{Number of pods plant ${ }^{-1}$}

The intercropping effect on pods plant ${ }^{-1}$ of mashbean was significant. The average across two years showed two years showed that sole crop produced significantly greater number of pods plant $^{-1}$ (27.97) than that grown as intercrop under different geometric arrangements. As regards the planting patterns, mashbean intercropped in sesame grown under the pattern of $100 \mathrm{~cm}$ spaced 4-row strips produced significantly greater number of pods plant ${ }^{-1}(25.98)$ than that intercropped under the pattern of $60 \mathrm{~cm}$ spaced paired rows (24.17). By contrast, the minimum pods plant ${ }^{-1}$ (22.19) was recorded when mashbean was intercropped in sesame planted in $40 \mathrm{~cm}$ spaced single rows. Khan and Khaliq (2004) and Bhatti et al. (2008) also reported similar findings when soybean was intercropped with cotton and mungbean intercropped with sesame.

\section{Number of seeds pod ${ }^{-1}$}

Mashbean intercropped in sesame irrespective to geometric arrangement or grown as sole crop produced statistically similar number of seeds pod $^{-1}$ as recorded for sole crop which on an average ranged between 5.25 and 5.40 .

\section{Number of seeds plant ${ }^{-1}$}

There were significant differences among different planting patterns with regard to seeds plant $^{-1}$. Monocropped mashbean produced significantly greater number of seeds plant $^{-1}$ (144.10) than that grown as intercrops under different planting patterns. Within the planting pattern, mashbean intercropped in sesame grown in the pattern of $100 \mathrm{~cm}$ spaced 4-row strips produced significantly greater number of seeds plant ${ }^{-1}$ (132.30) than that intercropped in $60 \mathrm{~cm}$ spaced paired rows (121.20). Contrarily, the minimum seeds plant $^{-1}$ were recorded (105.10) when mashbean was intercropped in sesame planted in 40 $\mathrm{cm}$ spaced single rows. The variation in seeds plant $^{-1}$ under different planting patterns was 
ascribed to inter-species competition and dominant effect of sesame. Khan and Khaliq (2004) also reported variation in the number of seeds plant ${ }^{-1}$ of soybean under different intercropping systems. Bhatti et al. (2008) also favoured these results when mungbean was intercropped in sesame.

\section{Seed weight plant $^{-1}$}

Effect of intercropping on seed weight plant ${ }^{-1}$ of mashbean was significant. The crop grown alone in $40 \mathrm{~cm}$ spaced rows produced significantly higher seed weight plant $^{-1}(5.17 \mathrm{~g})$ than that grown as intercrop under different planting patterns. Among the planting patterns, mashbean intercropped in sesame grown in the pattern of $100 \mathrm{~cm}$ spaced 4row strips produced significantly higher seed weight plant $^{-1}(4.12 \mathrm{~g})$. By contrast, the minimum seed weight plant $^{-1}(3.26 \mathrm{~g})$ was recorded when mashbean was intercropped in sesame planted in 40 $\mathrm{cm}$ spaced single rows.

\section{0-seed weight $(\mathrm{g})$}

The crop grown alone in $40 \mathrm{~cm}$ spaced single rows or intercropped in the pattern of $100 \mathrm{~cm}$ spaced 4-row strips exhibited statistically similar 1000-seed weight of 37.04 and $36.18 \mathrm{~g}$, respectively while the minimum 1000 -seed weight $(32.50 \mathrm{~g})$ was recorded when mashbean was intercropped in sesame planted in $40 \mathrm{~cm}$ spaced single rows. These results are in line with the findings of Bhatti et al. (2008). On the contrary, Khan and Khaliq (2004) reported non-significant effect on 1000-seed weight of soybean when intercropped in cotton.

\section{Plant density $\left(\mathrm{m}^{-2}\right)$ at harvest}

Mashbean intercropped in all the three planting patterns had statistically equal plant density $\mathrm{m}^{-2}$ which was at par with that recorded for the sole crop of mashbean. However, the plant density $\mathrm{m}^{-2}$ on an average ranged between 25.76 to $26.21 \mathrm{~m}^{-2}$. These results are in line with the findings of Bhatti et al. (2008) who intercropped mungbean in sesame but not in agreement with those reported by Khan and Khaliq (2004) who found a significant reduction in plant population of soybean when intercropped in cotton.

\section{Plant height (cm)}

The crop grown alone in $40 \mathrm{~cm}$ spaced rows attained significantly more plant height $(56.31 \mathrm{~cm})$ than that grown as intercrops under different planting patterns. Within the planting patterns, mashbean intercropped in sesame planted in the pattern of $100 \mathrm{~cm}$ spaced 4-row strips attained significantly greater plant height $(53.96 \mathrm{~cm})$ than that intercropped in the pattern of $60 \mathrm{~cm}$ spaced paired rows $(51.89 \mathrm{~cm})$ against the minimum $(51.00$ $\mathrm{cm}$ ) when mashbean was intercropped in sesame planted in $40 \mathrm{~cm}$ spaced single rows. Bhatti et al. (2008) also reported significant effect on plant height of mungbean when intercropped in sesame. On the contrary, Khan and Khaliq (2004) reported non-significant effect on plant height of soybean when intercropped in cotton.

Table 1. Agro-economic performance of mashbean intercropped in sesame under different planting patterns.

\begin{tabular}{|c|c|c|c|c|c|}
\hline Parameters & $\begin{array}{l}40 \mathrm{~cm} \text { spaced } \\
\text { single rows } \\
(\mathrm{P} 1)\end{array}$ & $\begin{array}{l}60 \mathrm{~cm} \text { spaced } \\
\text { double rows } \\
(\mathrm{P} 2)\end{array}$ & $\begin{array}{l}100 \mathrm{~cm} \text { spaced } 4- \\
\text { row strips } \\
(\mathrm{P} 3)\end{array}$ & $\begin{array}{l}\text { Mashbean } \\
\text { alone } \\
(\mathrm{P} 4)\end{array}$ & LSD \\
\hline $\begin{array}{l}\text { Seed yield of base crop } \\
(\text { sesame) } \\
\left(\mathrm{kg} \mathrm{ha}^{-1}\right)\end{array}$ & $518.05 \mathrm{c}$ & $646.55 \mathrm{~b}$ & $687.40 \mathrm{a}$ & - & 21.86 \\
\hline Seed yield $\left(\mathrm{kg} \mathrm{ha}^{-1}\right)$ & $503.7 \mathrm{~d}$ & $621.2 \mathrm{c}$ & $703.10 \mathrm{~b}$ & $808.4 \mathrm{a}$ & 33.32 \\
\hline Stalk yield $\left(\mathrm{kg} \mathrm{ha}^{-1}\right)$ & $1834 \mathrm{~d}$ & $2133 \mathrm{c}$ & $2332 \mathrm{~b}$ & $2538 \mathrm{a}$ & 117.60 \\
\hline Biological yield $\left(\mathrm{kg} \mathrm{ha}^{-1}\right)$ & $2337 \mathrm{~d}$ & $2755 \mathrm{c}$ & $3036 \mathrm{~b}$ & $3345 \mathrm{a}$ & 149.90 \\
\hline Branches plant ${ }^{-1}$ & $4.15 \mathrm{~d}$ & $4.64 \mathrm{c}$ & $5.07 \mathrm{~b}$ & $6.28 \mathrm{a}$ & 0.22 \\
\hline Pods plant ${ }^{-1}$ & $22.19 \mathrm{~d}$ & $24.17 \mathrm{~d}$ & $25.98 \mathrm{~b}$ & $27.97 \mathrm{a}$ & 1.11 \\
\hline Seeds pod ${ }^{-1}$ & 5.25 & 5.29 & 5.38 & 5.40 & NS \\
\hline Seeds plant ${ }^{-1}$ & $105.1 \mathrm{~d}$ & $121.2 \mathrm{c}$ & $132.3 \mathrm{~b}$ & $144.1 \mathrm{a}$ & 3.14 \\
\hline Seed weight plant ${ }^{-1}$ & $3.26 \mathrm{~d}$ & $4.12 \mathrm{c}$ & $4.92 \mathrm{~b}$ & $5.17 \mathrm{a}$ & 0.16 \\
\hline 1000 -seed weight $(\mathrm{g})$ & $32.50 \mathrm{c}$ & $34.07 \mathrm{~b}$ & $36.18 \mathrm{a}$ & $37.04 \mathrm{a}$ & 0.89 \\
\hline Plant density $\mathrm{m}^{-2}$ & 25.76 & 25.89 & 26.14 & 26.21 & NS \\
\hline Plant height $(\mathrm{cm})$ & $51.00 \mathrm{~d}$ & $51.89 \mathrm{c}$ & $53.96 \mathrm{~b}$ & $56.31 \mathrm{a}$ & 0.71 \\
\hline Harvest index (\%) & $21.45 \mathrm{~d}$ & $22.55 \mathrm{c}$ & $23.16 \mathrm{~b}$ & $24.17 \mathrm{a}$ & 0.19 \\
\hline Seed protein $(\%)$ & 23.86 & 24.54 & 24.86 & 25.05 & NS \\
\hline $\begin{array}{l}\text { Net field benefits } \\
\left(\mathrm{Rs} \mathrm{ha}^{-1}\right)\end{array}$ & 13353 & 19443 & 21242 & 16866 & \\
\hline
\end{tabular}


Table 2. Economic analysis of intercropping mash bean with sesame at different geometric arrangements.

\begin{tabular}{lll}
\hline Gross field benefits $\left(\right.$ Rs. ha $^{-1}$ ) & & \\
\hline Geometric arrangements & Sesame alone & Sesame + mashbean \\
\hline $\mathrm{P}_{1}=40 \mathrm{~cm}$ spaced single rows & 20053 & 18755 \\
$\mathrm{P}_{2}=60 \mathrm{~cm}$ spaced paired rows & 19198 & 24843 \\
$\mathrm{P}_{3}=100 \mathrm{~cm}$ spaced 4-row strips & 19806 & 26643 \\
Total cost that vary (Rs. ha ${ }^{-1}$ ) & & \\
$\mathrm{P}_{1}=40 \mathrm{~cm}$ spaced single rows & 3120 & 5402 \\
$\mathrm{P}_{2}=60 \mathrm{~cm}$ spaced paired rows & 2220 & 5400 \\
$\mathrm{P}_{3}=100 \mathrm{~cm}$ spaced 4-row strips & 3120 & 5400 \\
Net field benefits (Rs. ha ${ }^{-1}$ ) & & \\
$\mathrm{P} 1=40 \mathrm{~cm}$ spaced single rows & 16933 & 13353 \\
$\mathrm{P} 2=60 \mathrm{~cm}$ spaced paired rows & 16978 & 19443 \\
$\mathrm{P} 3=100 \mathrm{~cm}$ spaced 4-row strips & 16686 & 21242 \\
\hline
\end{tabular}

\section{Harvest index $(\%)$}

The sole crop of mashbean exhibited significantly higher harvest index $(24.17 \%)$ than that recorded for mashbean intercropped in different geometric arrangements. Among the planting patterns, mashbean intercropped in sesame grown in the pattern of $100 \mathrm{~cm}$ spaced 4-row strips gave significantly higher harvest index $(23.16 \%)$ than that intercropped in the pattern of $60 \mathrm{~cm}$ spaced paired rows $(22.55 \%)$. However, the minimum $(21.45 \%)$ harvest index was recorded when mashbean was intercropped in sesame planted in $40 \mathrm{~cm}$ spaced single rows. Reduction in harvest indices as a result of intercropping was also reported by Bhatti et al. (2008) when mungbean was intercropped in sesame but Khan and Khaliq (2004) reported non-significant effect on H.I when soybean was sown in association with cotton.

\section{Crude seed protein concentration (\%)}

The protein concentration in mashbean seed of a sole crop was statistically equal to that intercropped in sesame under all the three geometric arrangements. The seed protein concentration, however, on an average ranged between 23.86 and $25.05 \%$. These results are in line with those of Bhatti et al. (2008).

\section{Economic analysis}

The net benefits of intercropping mashbean in the pattern of $100 \mathrm{~cm}$ spaced 4-row strips or $60 \mathrm{~cm}$ spaced paired rows of sesame was higher (Rs.21242 $\mathrm{ha}^{-1}$ ) than that achieved from planting sesame at $60 \mathrm{~cm}$ spaced paired rows (19443) and 40 $\mathrm{cm}$ spaced single rows (13353) (Table 2). Hence, it is recommended that small farmers with limited resources may adopt the practice of sesame + mashbean intercropping preferably in the form of $100 \mathrm{~cm}$ spaced 4-row strips planting system of sesame.

\section{Conclusion}

It is concluded that intercropping of mashbean in sesame grown in the pattern of $100 \mathrm{~cm}$ spaced 4row strips is more economical and remunerative than intercropping of mashbean in sesame in the pattern of $40 \mathrm{~cm}$ spaced single rows and $60 \mathrm{~cm}$ spaced double rows.

\section{References}

Ahmad, R., A. Jabbar, A. H. Ahmad, Ehsanullah and I. H. Bhatti. 2007. Evaluation of direct seeded upland rice-based intercropping systems under strip planting geometry. Pak. J. Agri. Sci. 44(02):189-193.

Anonymous, 2012. Economic survey of Pakistan. 2011-12. Ministry of Food, Agriculture and Livestock wing, Islamabad.pp.45.

Bhatti, I. H., R. Ahmad, A. Jabbar, Z. A. Virk and M. Aslam. 2008. Agro-economic performance of mungbean intercropped in sesame under different planting patterns. Pak. J. Agri. Sci. 45(3):25-28.

Freed, R. D. and Eisensmith. 1986. MSTAT-C micro-computer statistical programme. Michigan State Univ. Agric., Michigan, Lansing, USA.

Jabbar, A., R. Amad, E. Ulla and S. Nazir. 2005. Agronomic approaches for productivity enhancement of upland rice-based intercropping systems under strip plantation. Pak. J. Agri. Sci. 42 (1-2):14-17.

Jabbar, A., R. Ahmad, I. H. Bhatti, Z. A. Virk, W. Din and M. M. Khan. 2009. Assessment of yield advantages, competitiveness and economic benefits of diversified direct seeded upland rice-based intercropping systems under strip geometry of planting. Pak. J. Agri. Sci. 46(02):96-101. 
Jabbar, A., R. Ahmad, I. H. Bhatti, A. Rehman, Z. A. Virk and S. N. Vains. 2010a. Effect of different rice-based intercropping systems on rice grain yield and residual soil fertility. Pak. J. Bot. 42(04):2339-2348.

Jabbar, A., R. Ahmad, I. H. Bhatti, W. Din, M. Nadeem and M. M. Khan. 2010b. Evaluating the performance of direct seeded rice in different intercropping systems under strip plantation. Int. J. Agric. Biol. 12(04):501-508.

Jabbar, A., R. Ahmad, I. H. Bhatti, T. Aziz, M. Nadeem, W. Din and A. Rehman. 2011. residual soil fertility as influenced by diverse rice-based inter/relay cropping systems. Int. J. Agric. Biol. 13(04):477-483.
Khan, M. B. and A. Khaliq. 2004. Production of soybean (Glycine max L.) as cotton based intercrop. J. Res. Sci. 15(01):79-84.

Nazir, M. S., M. Imran, A. Jabbar and M. Saeed. 2001. Agro-economic benefits of proportional wheat-gram intercropping under strip plantation. Pak. J. Biol. Sci. (01):75-77.

Steel, R. G. D., J. H. Torrie and D. A. Dicky. 1997. Principles and procedures of statistics- a biometrical approach. $3^{\text {rd }}$ Ed. McGraw Hill Book Co. Inc., New York. pp.400-428.

Wahla, I. H., R. Ahmad, Ehsan Ullah, Ashfaq Ahmad and A. Jabbar. 2009. Competition functions of component crops in Barley-based intercropping systems. Int. J. Agric. Biol. 11:69-72. 